\title{
Safety and Effectiveness of Recombinant Human Growth Hormone in Children with Turner Syndrome: Data from the PATRO Children Study
}

\author{
Philippe Backeljauw $^{\mathrm{a}}$ Shankar Kanumakala ${ }^{\mathrm{b}}$ Sandro Loche ${ }^{\mathrm{c}}$ \\ Karl Otfried Schwab ${ }^{d}$ Roland Werner Pfäffle ${ }^{e}$ Charlotte Höybye ${ }^{f, g}$ \\ Elena Lundberg ${ }^{\mathrm{h}}$ Tadej Battelino ${ }^{\mathrm{i}}$ Berit Kriström ${ }^{\mathrm{h}}$ Tomasz Giemza $^{j}$ \\ Hichem Zouaterk
}

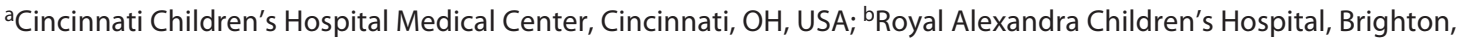

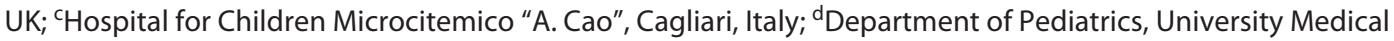

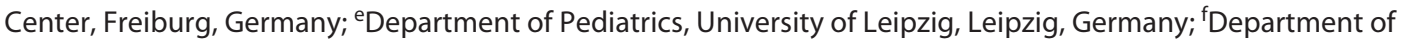
Endocrinology, Karolinska University Hospital, Solna, Sweden; 9Department of Molecular Medicine and Surgery, Karolinska Institute, Stockholm, Sweden; ' Institute of Clinical Science/Pediatrics, Umeå University, Umeå, Sweden; 'Department of Paediatric Endocrinology, Diabetes and Metabolic Diseases, University Medical Centre-University Children's Hospital, and University of Ljubljana, Ljubljana, Slovenia; 'Sandoz Poland, Warsaw, Poland; kSandoz $\mathrm{GmbH}$, Holzkirchen, Germany
\end{abstract}

\section{Keywords}

Turner syndrome $\cdot$ Pediatric endocrinology $\cdot$ Growth hormone replacement therapy · PATRO Children

\begin{abstract}
Introduction: PATRO Children is an international, observational, postmarketing surveillance study for a biosimilar recombinant human growth hormone (rhGH; somatropin, Omnitrope ${ }^{\circledR}$; Sandoz), approved by the European Medicines Agency in 2006. We report safety and effectiveness data for patients with Turner syndrome (TS). Methods: The study population included infants, children, and adolescents with TS who received Omnitrope ${ }^{\circledR}$ treatment according to standard clinical practice. Adverse events (AEs) were monitored for safety evaluation, and height velocity (HV), height standard deviation score (HSDS), and HVSDS were calculated to evaluate treatment effectiveness. Results: As of August
\end{abstract}

karger@karger.com www.karger.com/hrp

Karger $\stackrel{\text { ' }}{5}$

BOPEN ACCESS
(C) 2021 The Author(s)

Published by S. Karger AG, Basel

This is an Open Access article licensed under the Creative Commons Attribution-NonCommercial-4.0 International License (CC BY-NC) (http://www.karger.com/Services/OpenAccessLicense), applicable to the online version of the article only. Usage and distribution for commercial purposes requires written permission.
2019, 348 TS patients were enrolled from 130 centers. At baseline, 314 patients $(90.2 \%)$ were prepubertal and 284 patients (81.6\%) were rhGH treatment naïve. The mean (range) age at baseline was 9.0 (0.7-18.5) years, and mean (SD) treatment duration in the study was 38.5 (26.8) months. Overall, 170 patients $(48.9 \%)$ reported $\mathrm{AEs}$, which were considered treatment related in 25 patients (7.2\%). One treatment-related serious $A E$ was reported (intracranial hypertension). Mean $\triangle$ HSDS after 3 years of therapy was +1.17 in treatment-naïve prepubertal patients and +0.1 in pretreated prepubertal patients. In total, 51 patients (31.1\%) reached adult height $(\mathrm{AH})$, 35 of whom were rhGH treatment naïve; in these patients, mean (SD) HSDS was -2.97 (1.03) at the start of Omnitrope ${ }^{\circledR}$ treatment, and they achieved a mean (SD) AHSDS of -2.02 (0.9). Conclusion: These data suggest that biosimilar rhGH is well tolerated and effective in TS patients managed in reallife clinical practice. Optimization of rhGH dose may contribute to a higher $\mathrm{AH}$.

(C) 2021 The Author(s)

Published by S. Karger AG, Basel
Correspondence to:

Hichem Zouater, hichem.zouater@sandoz.com 


\section{Introduction}

Turner syndrome (TS) is characterized by partial or complete loss of the second sex chromosome in phenotypic females. A variety of genotypes exist in TS, although 45 , $\mathrm{X}$ (monosomy $\mathrm{X}$ ) is the most observed karyotype, affecting $40-50 \%$ of patients [1]. There is a wide variation in the clinical presentation of TS, and the observed karyotype does not necessarily predict patient phenotype [1]. Comorbidities include (but are not limited to) cardiovascular abnormalities, ovarian failure, neurocognitive or behavioral problems, and growth failure [2-4]. Short stature, especially in relation to parental height, is a very common occurrence in TS patients [1] and is caused by haploinsufficiency of the short stature homeobox-containing gene (SHOX) located on the sex chromosomes [5].

Recombinant human growth hormone (rhGH) therapy was approved for the treatment of TS in 1996 [6]. Randomized trials and observational studies have shown rhGH to improve adult height $(\mathrm{AH})$ in patients with TS, although the reported efficacy has been variable [7-9]. Factors associated with a good response to rhGH therapy include initiating rhGH treatment at a young age and use of higher rhGH doses [10-12]. Other factors affecting treatment response include weight and height standard deviation score (HSDS) at treatment start and the difference between midparental height SDS and baseline HSDS [10-13].

Data from clinical trials have demonstrated that rhGH treatment is generally well tolerated in TS patients [10, 13]. However, observational studies have reported that TS patients have an increased risk of intracranial hypertension, slipped capital femoral epiphyses, pancreatitis, and development/progression of scoliosis, compared with rhGH use in other indications $[14,15]$.

Omnitrope $^{\circledR}$ is an rhGH approved by the European Medicines Agency (EMA) and the US Food and Drug Administration (FDA) in 2006. It was approved as a biosimilar in Europe on the basis that it matches the reference medicine (Genotropin ${ }^{\circledR}$; Pfizer) in terms of safety, efficacy, and quality [16]. The PAtients TReated with Omnitrope ${ }^{\circledR}$ (PATRO) Children study is a long-term, postmarketing surveillance program for Omnitrope ${ }^{\circledR}$ $[17,18]$. The primary objective of PATRO Children is to assess the safety of rhGH in all approved indications. Effectiveness of rhGH is analyzed as a secondary endpoint [18]. Here, we present safety and effectiveness data from the subgroup of patients in PATRO Children who have TS.

\section{Methods}

\section{Study Design and Patient Population}

The design of the PATRO Children study has been previously reported [18]. In brief, infants, children, and adolescents who have received at least 1 dose of Omnitrope ${ }^{\circledR}$ were enrolled. Patients could be rhGH treatment naïve at study entry or previously treated with another rhGH medicine. Omnitrope ${ }^{\circledR}$ was administered as per standard clinical practice, and doses were given according to country-specific prescribing information. Patients and/or their guardians (for patients aged $<18$ years) provided written informed consent to participate in the study.

\section{Safety and Effectiveness Assessments}

All adverse events (AEs) were monitored and recorded for the duration of Omnitrope ${ }^{\circledR}$ treatment. AEs were recorded in electronic case report forms (eCRFs) and entered into the sponsor's safety database. The relationship of AEs to treatment was made according to investigator and sponsor assessment, with worst-case scenarios applying. Emphasis was placed on safety, including the development and reoccurrence of malignancies. Laboratory values, including glucose metabolism, were suggested to be recorded at baseline and at least once a year during the study. AEs are summarized for the subgroup of patients with TS and for the overall PATRO Children study population.

Auxological data were recorded at each visit. Height velocity (HV, cm/year), HSDS, HVSDS, and BMISDS were derived from height and weight measurements and country-specific reference tables for each country [19]. Target height and target height SDS were calculated using previously published methods [20-22]. AHSDS was calculated using height (in $\mathrm{cm}$ ) and appropriate height reference data at age 18 years. Patients were considered to have reached $\mathrm{AH}$ if the investigator identified one of the following reasons for study discontinuation: reaching AH/bone age maturation, reaching near $\mathrm{AH}$, referral to adult endocrinologist, $\mathrm{HV}<1 \mathrm{~cm} /$ year plus bone age $>14$ years for girls, $\mathrm{HV}<1 \mathrm{~cm} /$ year if start of puberty was documented, and any height measurement was available $\geq 4$ years after puberty onset.

\section{Data Collection and Statistical Analysis}

Patient data were recorded in an eCRF at each routine visit. All eCRFs were reviewed by data management, and centralized monitoring was performed by a contract research organization.

Standard descriptive statistics were used to describe continuous (e.g., age, height, and weight) and categorical (e.g., gender) variables. The safety population for this analysis included all TS patients documented in the eCRF before the interim analysis cutoff date (August 2019). The effectiveness population was a subset of the safety population and includes all patients with documented height measurement at baseline (start of Omnitrope ${ }^{\circledR}$ treatment) and at least 1 measurement of height under Omnitrope ${ }^{\circledR}$ treatment, at least 60 days after baseline. The 3-year analysis set includes patients who have completed at least 3 years of Omnitrope ${ }^{\circledR}$ therapy in the study.

\section{Results}

\section{Patients and Treatment (Safety Set)}

As of August 2019, 348 patients with TS had been enrolled in the study from 130 centers (Table 1); of these, 64 
Table 1. Number of sites and patient enrollment by country

\begin{tabular}{lllll}
\hline Country & $\begin{array}{l}\text { Sites, } \\
n\end{array}$ & $\begin{array}{l}\text { Enrolled } \\
\text { patients, } n\end{array}$ & $\begin{array}{l}\text { Active } \\
\text { patients, } n(\%)\end{array}$ & $\begin{array}{l}\text { Discontinued } \\
\text { patients, } n(\%)\end{array}$ \\
\hline Germany & 53 & 170 & $102(60.0)$ & $68(40.0)$ \\
France & 24 & 56 & $27(48.2)$ & $29(51.8)$ \\
Romania & 18 & 53 & $21(39.6)$ & $32(60.4)$ \\
United Kingdom & 9 & 20 & $12(60.0)$ & $8(40.0)$ \\
Sweden & 5 & 16 & $9(56.3)$ & $7(43.8)$ \\
Czech Republic & 4 & 9 & $0(0.0)$ & $9(100.0)$ \\
USA & 6 & 9 & $0(0.0)$ & $9(100.0)$ \\
Italy & 4 & 5 & $1(20.0)$ & $4(80.0)$ \\
Canada & 4 & 4 & $3(75.0)$ & $3(100.0)$ \\
Slovenia & 1 & 3 & $0(0.0)$ & $2(100.0)$ \\
Austria & 1 & 2 & $0(0.0)$ & $0(0.0)$ \\
Australia & 1 & 1 & $1(100.0)$ & $172(49.4)$ \\
\hline Total & 130 & 348 & $176(50.6)$ &
\end{tabular}

Table 2. Patient baseline characteristics (safety set)

\begin{tabular}{llllllll}
\hline & $N$ & $\begin{array}{l}\text { Pubertal/ } \\
\text { prepubertal, } \%\end{array}$ & $\begin{array}{l}\text { Mean (range) age, } \\
\text { years }\end{array}$ & $\begin{array}{l}\text { Mean (SD) } \\
\text { BMI SDS }\end{array}$ & $\begin{array}{l}\text { Mean (SD) } \\
\text { HSDS }\end{array}$ & $\begin{array}{l}\text { Mean (SD) HVa, } \\
\text { cm/year }\end{array}$ & $\begin{array}{l}\text { Mean (SD) PC } \\
\text { HVSDS }\end{array}$ \\
\hline All & 348 & $9.8 / 90.2$ & $8.96(0.7-18.5)$ & $0.31(1.18)$ & $-2.78(1.14)$ & $3.60(1.82)$ & $-2.43(2.38)$ \\
\hline rhGH naïve & 284 & $6.0 / 94.0$ & $8.54(0.7-18.5)$ & $0.20(1.18)$ & $-3.00(1.03)$ & $3.39(1.68)$ & $-3.08(1.85)$ \\
Pretreated & 64 & $26.6 / 73.4$ & $10.84(2.9-18.0)$ & $0.81(1.02)$ & $-1.80(1.12)$ & $3.99(2.00)$ & $-1.23(2.78)$ \\
\hline
\end{tabular}

$\mathrm{AH}$, adult height; HV, height velocity; HSDS, height standard deviation score; SD, standard deviation; HVSDS, HV standard deviation score; PC, peak-centered; rhGH, recombinant human growth hormone. ${ }^{\text {a }}$ Only for patients who had not attained AH.

(18.4\%) had previously received rhGH treatment and 284 (81.6\%) were rhGH treatment naïve. At baseline (start of Omnitrope ${ }^{\circledR}$ treatment), 314 patients $(90.2 \%)$ were prepubertal, and the remaining 34 patients $(9.8 \%)$ had entered puberty. Additional baseline characteristics are shown in Table 2. In prepubertal patients, mean (SD) age at baseline was $8.2(4.0)$ years and 9.8 (3.5) years in treatment-naïve and pretreated patients, respectively. Karyotype was reported in $94.5 \%$ of patients (Table 3 ), and for the remaining patients, the karyotype was not entered in the eCRF.

The mean (SD) duration of Omnitrope ${ }^{\circledR}$ treatment in the study was 38.5 (26.8) months (approx. 3.2 years; $1,116.6$ patient-years). In total, 196 patients $(56.3 \%)$ had completed 3 years of treatment. In pretreated patients, the mean (SD) duration of rhGH therapy prior to starting the study was 51.4 (34.0) months (approx. 4.3 years). The mean (range) baseline dose was $38.5(10.0-67.0) \mu \mathrm{g} / \mathrm{kg} /$ day in rhGH treatment-naïve patients and 43.2 (22.0-
$60.0) \mu \mathrm{g} / \mathrm{kg} /$ day in pretreated patients. The initial starting dose was $45-50 \mu \mathrm{g} / \mathrm{kg} /$ day in $22.2 \%$ of rhGH treatmentnaïve patients and in $20.3 \%$ of pretreated patients. In the remaining patients, the initial starting dose was outside of this range (rhGH naive, $57.4 \%$; pretreated, $57.8 \%$ ) or not recorded (rhGH naïve, 20.4\%; pretreated, 21.9\%). Following 1-1.5 years of Omnitrope ${ }^{\circledR}$ therapy, the mean (range) dose increased to $44.1(0.02-87.0) \mu \mathrm{g} / \mathrm{kg} / \mathrm{day}$ in treatment-naïve patients and $45.1(26.0-64.0) \mu \mathrm{g} / \mathrm{kg} /$ day in pretreated patients.

No patients received estrogen treatment prior to entering the study. During the study, 84 treatment-naïve patients $(29.6 \%)$ received concomitant estrogen, including estradiol ( $n=37 ; 13.0 \%)$, estradiol valerate $(n=33 ; 11.6 \%)$, ethinyl estradiol ( $n=7 ; 2.5 \%)$, conjugated estrogens $(n=$ $3 ; 1.1 \%)$, estradiol hemihydrate $(n=2 ; 0.7 \%)$, estrogen (not otherwise specified) ( $n=2 ; 0.7 \%)$, and estriol with estradiol ( $n=1 ; 0.4 \%)$. Forty pretreated patients $(64.1 \%)$ received concomitant estrogen during the study, includ- 
Table 3. Genetic abnormalities identified (safety set)

\begin{tabular}{|c|c|c|}
\hline Genetic abnormality & $\begin{array}{l}\text { Treatment-naïve patients, } \\
n(\%)(n=248)\end{array}$ & $\begin{array}{l}\text { Pretreated patients, } \\
n(\%)(n=64)\end{array}$ \\
\hline Complete absence of 1 sex chromosome (karyotype $45, \mathrm{X}$ ) & $89(31.3)$ & $26(40.6)$ \\
\hline Mean (SD) age at rhGH treatment start, years & $8.52(4.61)$ & $7.15(4.44)$ \\
\hline Mean (SD) target height SDS & $0.01(0.75)$ & $-0.27(0.73)$ \\
\hline Mean (SD) rhGH (Omnitrope ${ }^{\circledR}$ ) dose at baseline, $\mu \mathrm{g} / \mathrm{kg} /$ day & $39.3(11.4)$ & $44.2(8.3)$ \\
\hline Mosaicism (karyotype 45,X/46,XX) & $78(27.5)$ & $13(20.3)$ \\
\hline Mean (SD) age at rhGH treatment start, years & $8.08(3.58)$ & $5.74(2.50)$ \\
\hline Mean (SD) target height SDS & $-0.15(0.72)$ & $-0.35(0.60)$ \\
\hline Mean (SD) rhGH (Omnitrope ${ }^{\circledR}$ ) dose at baseline, $\mu \mathrm{g} / \mathrm{kg} /$ day & $38.6(9.8)$ & $43.5(7.8)$ \\
\hline Partial absence of 1 sex chromosome (karyotype 45,X/46,X,delX) & $16(5.6)$ & $5(7.8)$ \\
\hline Mean (SD) age at rhGH treatment start, years & $10.17(4.41)$ & $6.78(3.74)$ \\
\hline Mean (SD) target height SDS & $-0.10(1.37)$ & $-0.01(0.66)$ \\
\hline Mean (SD) rhGH (Omnitrope ${ }^{\circledR}$ ) dose at baseline, $\mu \mathrm{g} / \mathrm{kg} /$ day & $40.5(10.9)$ & $38.3(10.4)$ \\
\hline Structural aberrations (karyotype $45, \mathrm{X} / 46, \mathrm{X}, \mathrm{rX}$ ) & $12(4.2)$ & $2(3.1)$ \\
\hline Mean (SD) age at rhGH treatment start, years & $7.84(4.65)$ & $3.72(1.02)$ \\
\hline Mean (SD) target height SDS & $0.02(0.73)$ & $-0.34(0.44)$ \\
\hline Mean (SD) rhGH (Omnitrope ${ }^{\circledR}$ ) dose at baseline, $\mu \mathrm{g} / \mathrm{kg} /$ day & $41.8(14.2)$ & $50.0(\mathrm{~N} / \mathrm{A})$ \\
\hline Others & $72(25.4)$ & $14(21.9)$ \\
\hline Mean (SD) age at rhGH treatment start, years & $8.82(4.28)$ & $6.30(3.98)$ \\
\hline Mean (SD) target height SDS & $0.10(0.67)$ & $-0.07(0.49)$ \\
\hline Mean (SD) rhGH (Omnitrope ${ }^{\circledR}$ ) dose at baseline, $\mu \mathrm{g} / \mathrm{kg} /$ day & $36.4(10.4)$ & $41.5(12.4)$ \\
\hline Missing information & $17(6.0)$ & $4(6.3)$ \\
\hline
\end{tabular}

rhGH, recombinant human growth hormone.

Table 4. Primary reasons for study discontinuation (safety set)

\begin{tabular}{lll}
\hline \multirow{2}{*}{ Total $(n=172)$} & \multicolumn{2}{l}{ Patients } \\
\cline { 2 - 3 } & $n$ & $\%$ \\
\hline Patient reached adult height/bone age maturation $^{\mathrm{a}}$ & 52 & 30.2 \\
Reached near adult height $^{\mathrm{a}}$ & 28 & 16.3 \\
Patient satisfied with current height $^{2}$ & 5 & 2.9 \\
Lost to follow-up $_{\text {Adverse event }}$ & 15 & 8.7 \\
Patient does not wish to continue the injections & 10 & 5.8 \\
Site closure & 9 & 5.2 \\
Switch to other GH medicine & 9 & 5.2 \\
No treatment response & 5.2 \\
Patient noncompliant & 6 & 3.5 \\
HV slowdown (HV <1 cm/year) & 3 & 1.7 \\
Referral to adult endocrinologist & 2 & 1.2 \\
Withdrawal of informed consent & 1 & 0.6 \\
Others & 1 & 0.6 \\
\end{tabular}

$\mathrm{GH}$, growth hormone; HV, height velocity; SDS, standard deviation score. ${ }^{a}$ According to physician assessment. ${ }^{b}$ No treatment response defined as HVSDS $<1$ after first year of treatment; $\mathrm{HV}<2 \mathrm{~cm} /$ year postbaseline. If confirmation is required, bone age is $>14$ years for girls or $>16$ years for boys, corresponding to closure of epiphyseal growth plate (postbaseline). ing estradiol ( $n=25 ; 39.1 \%)$, estradiol valerate $(n=12$; $18.8 \%$ ), ethinyl estradiol ( $n=4 ; 6.3 \%)$, conjugated estrogens $(n=3 ; 4.7 \%)$, and estrogen not otherwise specified $(n=2 ; 3.1 \%)$.

No patients received oxandrolone treatment prior to entering the study. One pretreated patient received oxandrolone therapy during the study. This patient had been treated with another rhGH for 6 years before entering the study at 11 years of age. At the time of analysis, this patient had received Omnitrope ${ }^{\circledR}$ treatment in the study for over 5 years, with a daily dose ranging between 44 and 47 $\mu \mathrm{g} / \mathrm{kg} / \mathrm{day}$. HSDS was -3.18 at baseline and -2.72 following 5.5 years of Omnitrope ${ }^{\circledR}$ treatment in the study.

The most common reported comorbidities (present in $\geq 2 \%$ of patients) by MedDRA preferred term were hypothyroidism $(n=24 ; 6.9 \%)$, autoimmune thyroiditis $(n=$ $23 ; 6.6 \%)$, congenital heart valve disorder $(n=18 ; 5.2 \%)$, primary hypogonadism $(n=14 ; 4.0 \%)$, vitamin $\mathrm{D}$ deficiency $(n=13 ; 3.7 \%)$, obesity $(n=10 ; 2.9 \%)$, otitis media $(n=10 ; 2.9 \%)$, coeliac disease $(n=9 ; 2.6 \%)$, hypertension $(n=8 ; 2.3 \%)$, hypercholesterolemia $(n=8 ; 2.3 \%)$, renal fusion anomaly $(n=8 ; 2.3 \%)$, foot deformity $(n=7 ; 2.0 \%)$, and asthma $(n=7 ; 2.0 \%)$. 
Table 5. Summary of AEs in patients with TS and in the overall PATRO Children study population

\begin{tabular}{|c|c|c|c|c|}
\hline & \multicolumn{2}{|c|}{ Patients with TS $(n=348)$} & \multicolumn{2}{|c|}{ All patients $(n=7,042)$} \\
\hline & $n$ & $\%$ & $n$ & $\%$ \\
\hline Any AE & 170 & 48.9 & 3,583 & 50.9 \\
\hline \multicolumn{5}{|l|}{ Relationship to study drug } \\
\hline Not suspected & 167 & 48.0 & 3,470 & 49.3 \\
\hline Suspected & 25 & 7.2 & 527 & 7.5 \\
\hline \multicolumn{5}{|l|}{ Intensity } \\
\hline Mild & 139 & 39.9 & 2,797 & 39.7 \\
\hline Moderate & 85 & 24.4 & 1,556 & 22.1 \\
\hline Severe & 14 & 4.0 & 334 & 4.7 \\
\hline Missing & 32 & 9.2 & 690 & 9.8 \\
\hline \multicolumn{5}{|l|}{ Changes to rhGH treatment } \\
\hline Not changed & 163 & 46.8 & 3,406 & 48.4 \\
\hline Increased & 9 & 2.6 & 138 & 2.0 \\
\hline Reduced & 5 & 1.4 & 87 & 1.2 \\
\hline Interrupted & 8 & 2.3 & 191 & 2.7 \\
\hline Permanently discontinued & 10 & 2.9 & 122 & 1.7 \\
\hline Missing & 9 & 2.6 & 156 & 2.2 \\
\hline \multicolumn{5}{|l|}{ SAEs } \\
\hline No & 160 & 46.0 & 3,423 & 48.6 \\
\hline Yes & 49 & 14.1 & 915 & 13.0 \\
\hline \multicolumn{5}{|l|}{ SAE relationship to study drug } \\
\hline Not suspected & 48 & 13.8 & 877 & 12.5 \\
\hline Suspected & 1 & 0.3 & 59 & 0.8 \\
\hline
\end{tabular}

AE, adverse event; MedDRA, Medical Dictionary for Regulatory Activities; SAE, serious adverse event; rhGH, recombinant human growth hormone; TS, Turner syndrome.

Abnormal values for thyroid function were recorded in 27 out of 348 patients (7.8\%) at baseline (before start of Omnitrope ${ }^{\circledR}$ treatment). Over 5 years of treatment, the proportion of patients with abnormal thyroid test results was between 2.6 and $9.3 \%$.

\section{Safety (Safety Set)}

As of August 2019, 172 TS patients (49.4\%) had discontinued the study; primary reasons for discontinuation are shown in Table 4. Ten patients (2.9\%) discontinued due to an AE (Table 5), which was considered rhGH treatment related in 7 patients ( $2.0 \% ; n=9$ events). Treatment-related AEs leading to discontinuation were increased weight $(n=2)$, insulin-like growth factor increased $(n=1)$, glucose tolerance impaired $(n=1)$, hyperinsulinism $(n=1)$, overweight $(n=1)$, headache $(n=1)$, intracranial hypertension $(n=1)$, and scoliosis $(n=1)$.

The overall summary of AEs in the TS patients was similar to that of the overall PATRO Children study population (Table 5). Among patients with TS, 170 (48.9\%) experienced AEs during the study, most of which were of mild or moderate intensity (Table 4). In total, 25 patients with TS (7.2\%) reported drug-related AEs; events reported in $\geq 2$ patients (MedDRA preferred term) were headache $(n=4)$, glucose tolerance impaired $(n=4)$, insulinlike growth factor increased $(n=2)$, injection-site hematoma $(n=2)$, and weight increased $(n=2)$. Forty-nine patients (14.1\%) reported serious AEs (SAEs). Only 1 patient had an SAE that was possibly related to treatment (intracranial hypertension). This SAE was reported 3 months after the start of Omnitrope ${ }^{\circledR}$ treatment in a patient who was rhGH treatment naive at study entry; at the time of onset, the patient was 11.4 years old, and the dose of Omnitrope ${ }^{\circledR}$ was $48.0 \mu \mathrm{g} / \mathrm{kg} /$ day. Omnitrope ${ }^{\circledR}$ therapy was discontinued, and the event resolved completely after approximately 2 years.

In total, 13 patients $(3.7 \%)$ reported scoliosis, which was treatment related in 1 patient $(0.3 \%)$. Pancreatitis was reported in 1 patient $(0.3 \%)$; this event was considered serious but not related to rhGH therapy.

No AEs with a fatal outcome were reported. To date, there have been no reports of treatment-related SAEs re- 


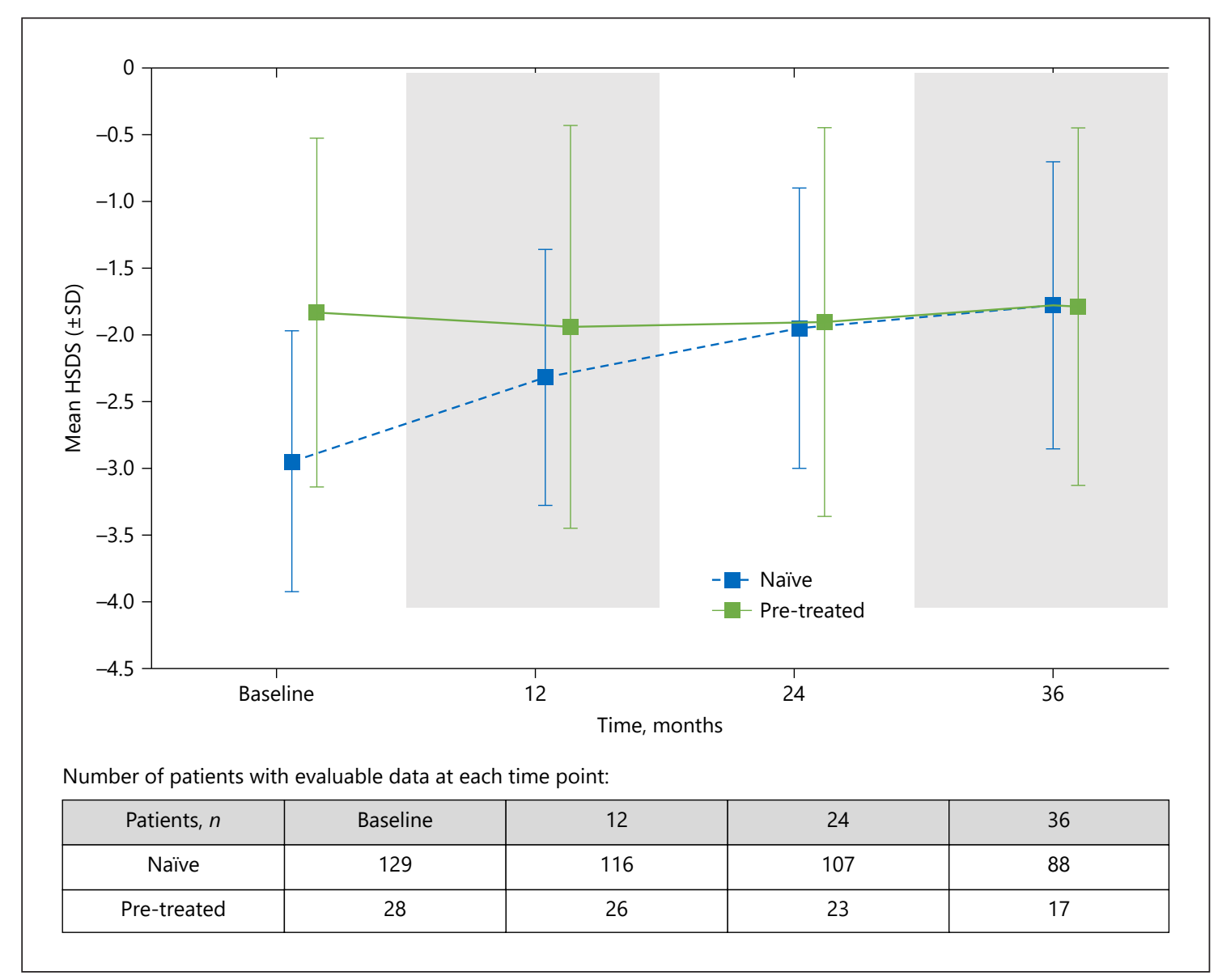

Fig. 1. HSDS for TS patients remaining prepubertal over 3 years of Omnitrope ${ }^{\circledR}$ treatment (3-year efficacy set). HSDS, height standard deviation score; TS, Turner syndrome.

lating to malignancies or diabetes mellitus. Treatmentrelated AEs relating to insulin sensitivity in this cohort include impaired glucose tolerance ( $n=4$ patients), hyperinsulinism $(n=1)$, and insulin resistance $(n=1)$, all of which were considered nonserious.

\section{Effectiveness (3-Year Cohort, Effectiveness Set)}

In total, 163 patients from the effectiveness set completed at least 3 years of treatment and were included in the 3-year effectiveness cohort. This included 131 treatment-naïve patients $(80.4 \%)$ and 32 pretreated patients (19.6\%). Of the 131 treatment-naïve patients, $129(98.5 \%)$ were prepubertal at baseline and 2 patients (1.5\%) had entered puberty. Of the pretreated patients, 29 (90.6\%) were prepubertal and $3(9.4 \%)$ had started puberty.

Improvements in mean HSDS and HVSDS over 3 years for patients remaining prepubertal are shown in
Figures 1 and 2. The mean gain in HSDS from baseline to year 3 was +1.17 in prepubertal treatment-naïve patients (year 1, +0.63 ; year 2, 0.37 ; year $3,+0.17$ ) and +0.04 in prepubertal pretreated patients. $\mathrm{AH}$ was reached by 51 patients $(31.1 \%)$ from the 3 -year effectiveness cohort; 35 of these patients were treatment naïve at study entry, and 16 patients were pretreated. Mean (SD) patient age when reaching AH was 15.9 (1.7) years in treatment-naïve patients and 15.7 (1.6) years in pretreated patients. Among the 35 treatment-naive patients who reached $\mathrm{AH}$, mean (SD) HSDS was -2.97 (1.03) at the start of Omnitrope ${ }^{\circledR}$ treatment; these patients achieved a mean (SD) AHSDS of -2.02 (0.9). A similar mean (SD) AHSDS -2.10 (1.1) was reached by the 16 pretreated patients.

The mean improvement in peak-centered HVSDS from baseline to year 3 was +3.94 in prepubertal treat- 


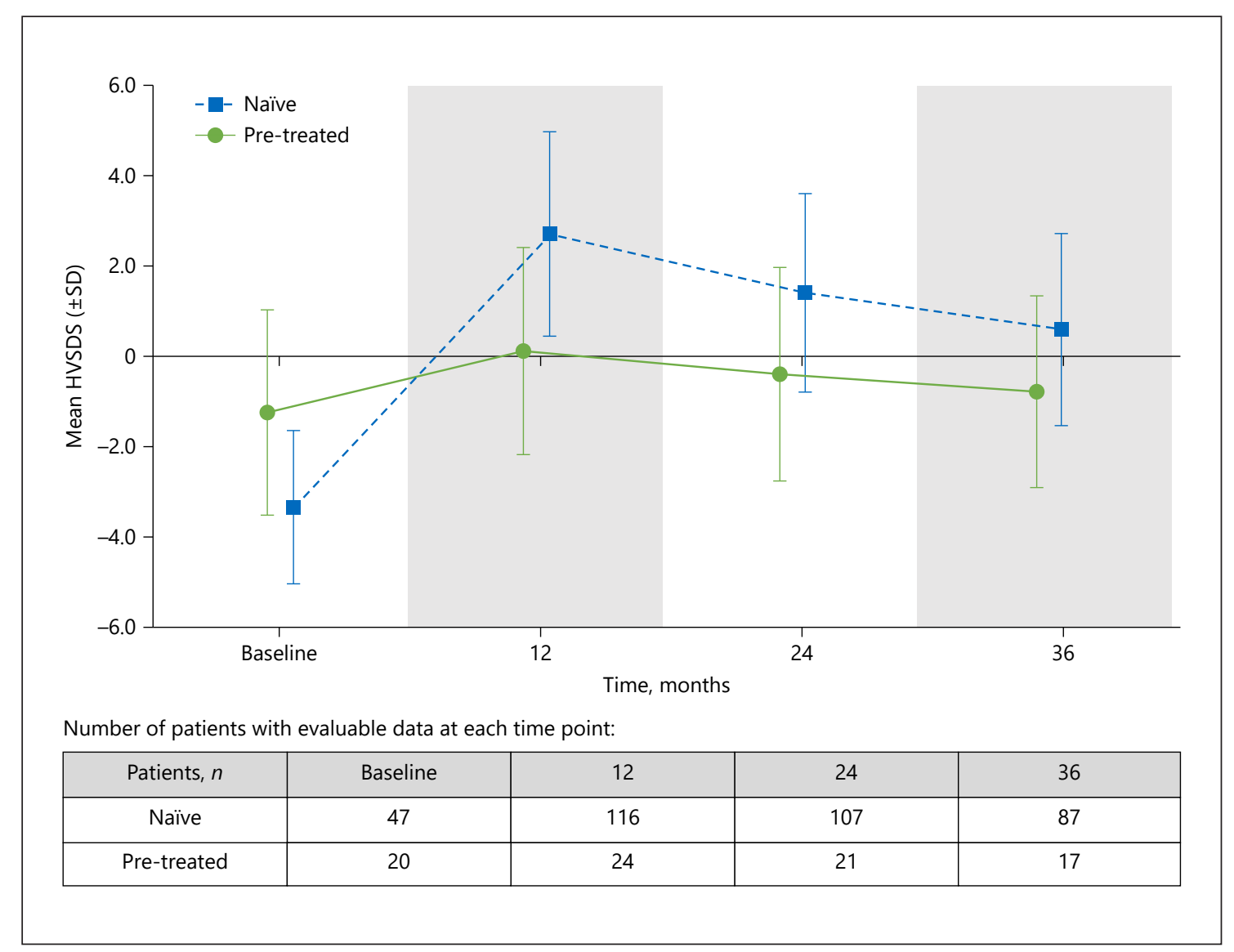

Fig. 2. Peak-centered HVSDS for TS patients remaining prepubertal over 3 years of Omnitrope ${ }^{\circledR}$ treatment (3year efficacy set). HV, height velocity; TS, Turner syndrome.

ment-naïve patients and +0.47 in prepubertal pretreated patients. Mean (SD) HV at year 3 was $5.9(1.5) \mathrm{cm} /$ year and $4.5(1.4) \mathrm{cm} /$ year in rhGH treatment-naïve and pretreated patients, respectively. In prepubertal patients, mean (SD) $\mathrm{HV}$ at year 3 was $5.2(1.3) \mathrm{cm} /$ year and 4.7 $(1.4) \mathrm{cm} /$ year in treatment-naïve and pretreated patients, respectively.

At year 3, mean (SD) BMI SDS was 0.3 (1.2) in prepubertal treatment-naïve patients, representing a mean (SD) change from baseline of $+0.4(0.8)$. In prepubertal pretreated patients, mean (SD) BMI SDS was 0.7 (1.1) at year 3, a mean (SD) change from baseline of $+0.1(0.7)$. In patients who reached $\mathrm{AH}$, the mean (SD) difference between AHSDS and target height SDS was -2.03 (0.9) in treatment-naïve patients, corresponding to a mean (SD) deficit of $11.8(6.4) \mathrm{cm}$. In pretreated patients, the mean (SD) difference was -1.82 (1.1), corresponding to a mean (SD) deficit of $9.6(6.9) \mathrm{cm}$.

rhGH in Children with Turner Syndrome: Data from PATRO Children
The change in HSDS over time by karyotype is shown in Figure 3 for treatment-naïve patients in the 3-year effectiveness cohort. Patients with classical TS $(45, \mathrm{X})$ had more severe short stature at baseline compared with mosaic TS patients $(45, \mathrm{X} / 46, \mathrm{XX})$. Across all of the karyotypes, improvement in HSDS was the largest in the 45 , X group (+1.32) and the smallest in the $45, \mathrm{X} / 46, \mathrm{XX}$ group.

\section{Discussion}

This analysis of an observational study of 348 girls with TS demonstrates that biosimilar rhGH (Omnitrope ${ }^{\circledR}$ ) therapy is well tolerated and effective in these patients in real-life clinical practice. These findings are in line with reports from other observational studies of rhGH treatment in pediatric TS patients, although differences in ob- 


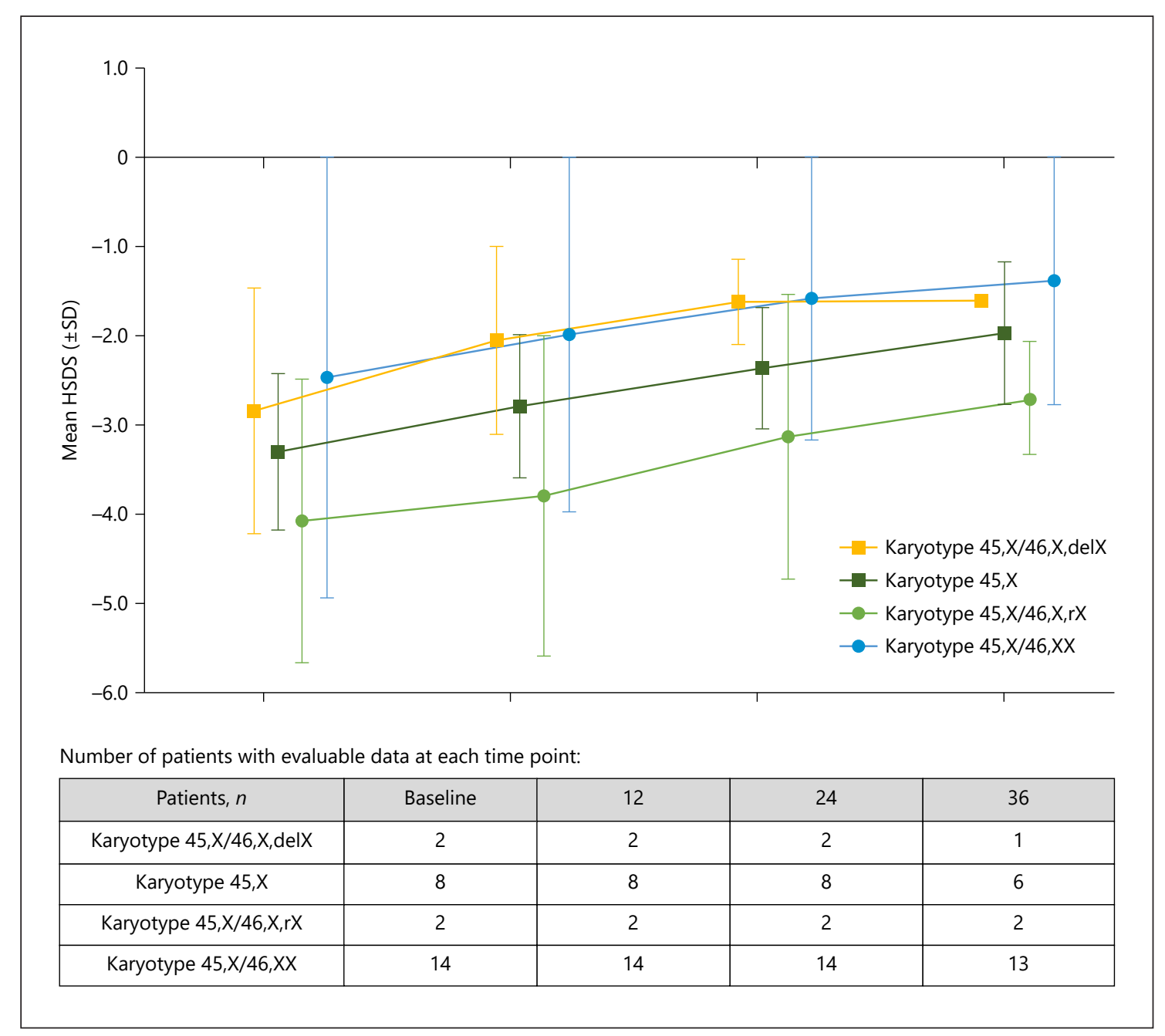

Fig. 3. HSDS for treatment-naïve TS patients by karyotype over 3 years of Omnitrope ${ }^{\circledR}$ treatment (3-year efficacy set). HSDS, height standard deviation score; TS, Turner syndrome.

servational time periods and reported outcomes make a direct comparison of results difficult.

An increased risk of intracranial hypertension, slipped capital femoral epiphyses, scoliosis, and pancreatitis has been reported in rhGH-treated patients with TS $[14,15]$. Another study found that TS patients have an increased risk of scoliosis, although this was not directly related to rhGH therapy [23]. The data from our study do not support an increased risk of these events due to rhGH therapy. However, as the treatment duration in the current analysis was relatively short, longer-term follow-up would be required to verify these safety findings. In addition, the data available in TS patients from this analysis show no evidence of an increased risk of developing unexpected AEs or new malignancies during rhGH treat- ment. The safety profile of rhGH treatment in TS patients was also consistent with the overall PATRO Children cohort, which additionally includes patients with GH deficiency, small for gestational age, Prader-Willi syndrome, chronic renal insufficiency, and idiopathic short stature [24].

Individuals with TS have an increased risk of developing autoimmune conditions such as thyroiditis, type 1 diabetes, juvenile rheumatoid arthritis, coeliac disease, and inflammatory bowel disease $[1,25]$. A meta-analysis of 18 studies (2,719 patients with TS) found that $12.7 \%$ had clinical hypothyroidism and $2.6 \%$ had hyperthyroidism [26]. The prevalence of thyroid dysfunction in patients with TS in PATRO Children appears to be lower than reported in the meta-analysis (based on reported co- 
morbidities and the number of abnormal thyroid function tests). The apparent underreporting of thyroid dysfunction, as well as some of the other comorbidities, most likely reflects the observational nature of PATRO Children.

Clinical practice guidelines for the care of girls and women with TS were published in 2017 [1]. Once diagnosed, starting rhGH treatment by $4-6$ years of age is recommended [1]. The guidelines further recommend initiating rhGH treatment earlier if there is evidence of growth failure. In PATRO Children, the mean patient age at rhGH treatment initiation was 8.5 years (in treatmentnaïve patients, who had mean baseline HSDS of -3.0). The diagnosis of TS is often delayed $[27,28]$, which could explain the late treatment initiation observed in PATRO Children. In one study of 81 TS patients, the mean (SD) delay in diagnosis was 7.7 (5.4) years in girls diagnosed in childhood or adolescence [28]. The varied clinical presentation of TS can also affect when the diagnosis is made; one study reported that lymphedema and dysmorphic features were the main symptoms that prompted screening in infancy, whereas short stature triggered diagnosis in most children and adolescents [27]. The study design did not allow a delay between TS diagnosis and the initiation of rhGH therapy.

The approved starting dose of rhGH in TS patients is $45-50 \mu \mathrm{g} / \mathrm{kg} /$ day in Europe [17] and 50-54 $\mu \mathrm{g} / \mathrm{kg} /$ day in the USA [29]. The 2017 clinical practice guidelines recommend starting at a dose of $45-50 \mu \mathrm{g} / \mathrm{kg} /$ day, increasing up to $68 \mu \mathrm{g} / \mathrm{kg} /$ day if the initial growth response is suboptimal [1]. In the current analysis, the starting dose in rhGH-naïve patients ranged from 10 to $67 \mu \mathrm{g} / \mathrm{kg} / \mathrm{day}$ (mean $38.5 \mu \mathrm{g} / \mathrm{kg} /$ day), and the mean dose remained lower than the recommended dose following 1-1.5 years of treatment $(44.1 \mu \mathrm{g} / \mathrm{kg} /$ day $)$. Only around $20 \%$ of treatment-naïve patients received a starting dose within the recommended range of $45-50 \mu \mathrm{g} / \mathrm{kg} / \mathrm{day}$. This is important, as the greatest effect on growth response is observed during the first year of treatment. These findings suggest that guideline-recommended rhGH doses may not always be closely adhered to in routine clinical practice. A lack of rhGH dose escalation in TS patients has been demonstrated in another observational study [30]. One explanation is that endocrinologists are cautious about increasing rhGH dose in girls with TS, although other data indicating reduced sensitivity to IGF-I in girls with TS may provide some reassurance [31]. It is also worth noting that patients with TS in PATRO Children will likely have started $\mathrm{rhGH}$ treatment before the updated guidelines were published in 2017.

rhGH in Children with Turner Syndrome: Data from PATRO Children
Clinical practice guidelines also suggest that the addition of oxandrolone to rhGH treatment may be considered in TS patients from the age of 10 years who have poor projected AH on rhGH therapy alone [1], although availability of oxandrolone outside the USA is limited. In our analysis, oxandrolone use was recorded in only 1 patient, who received rhGH therapy prior to entering PATRO Children. Based on data from several placebo-controlled studies, use of oxandrolone in rhGH-treated girls with TS increases AH by an average of 2.3-4.6 cm [32-35].

The effectiveness results from our analysis are broadly in line with those from other observational studies in TS patients. The Neuroendocrinology of Short Stature International Study (GeNeSIS) included treatment-naïve and pretreated TS patients $(n=886)$, whose baseline characteristics (mean baseline age 9.2 years and mean baseline HSDS -2.56) were comparable to the present study. In the GeNeSIS study, mean age at reaching $\mathrm{AH}$ was 17.2 years and near-adult HSDS was $-1.70(n=695)$, although these data are reported for the whole cohort, regardless of pubertal status and rhGH pretreatment [8]. Another analysis included data from treatment-naïve TS patients $(n=294)$ enrolled in the observational NordiNet ${ }^{\circledR}$ International Outcome Study and the American Norditropin Studies: Web-Enabled Research (ANSWER) Program [9]. The baseline characteristics of patients included (mean age 7.8 years and HSDS was -2.67) were again comparable to those of the TS patients enrolled in PATRO Children. At year 4, mean HSDS was -1.65 [9]; this $\triangle$ HSDS from baseline $(+1.0)$ is comparable to the year 3 $\Delta$ HSDS $(+1.2)$ in prepubertal treatment-naïve TS patients in PATRO Children.

The most common genetic variant in TS patients enrolled in PATRO Children was 45,X (monosomy X). A response to $\mathrm{GH}$ treatment was observed across all karyotypes, although patient numbers in the different groups were very small due to the population used for analysis (effectiveness set; patients who had completed 3 years of follow-up). Nevertheless, previous studies have reported that karyotype does not significantly influence response to rhGH therapy in TS patients $[11-13,36]$.

In the current analysis, approximately one-third of patients in the 3-year effectiveness set reached $\mathrm{AH}$. In treatment-naïve patients, mean adult HSDS was -2.0 , and the mean patient age at reaching $\mathrm{AH}$ was 16 years. The relatively late initiation of treatment may have contributed to the low adult HSDS observed. It is well recognized that children with short stature, including those with TS, show a greater response to $\mathrm{rhGH}$ if treatment is initiated at an early age [13].

Horm Res Paediatr 2021;94:133-143 141 
The PATRO Children study has several limitations, which are common to all observational studies. For example, there is a potential selection bias due to enrollment of patients from selected clinics in some countries. Additionally, there are differences in the management of TS patients across the different centers and countries included in the study. Furthermore, as data are collected according to routine clinical practice, there is a risk of bias as some recorded data may be incomplete. In order to reduce this risk of bias, eCRFs were reviewed by data management to identify discrepancies, and participating centers were visited twice a year by a contract research organization to monitor data.

\section{Conclusion}

This analysis demonstrates that treatment with biosimilar rhGH (Omnitrope $\left.{ }^{\circledR}\right)$ is well tolerated and effective in TS patients managed in real-life clinical practice. No unexpected or concerning safety signals were identified. However, several well-known AEs were observed, confirming the need for ongoing patient monitoring. Substantial height gains were observed in prepubertal individuals over 3 years of treatment, despite the use of doses at the lower end of those recommended. This study also indicates that rhGH treatment and estradiol supplementation can be further improved to help individuals with TS to attain AH closer to the population mean.

\section{Acknowledgment}

Medical writing support was provided by Tony Reardon of Aura, a division of Spirit Medical Communications Ltd., supported by Sandoz/Hexal AG. The authors thank Yu-Ming Shen (San-
doz/Hexal AG) for providing statistical support. The authors thank all patients and investigators who participated in the PATRO Children study.

\section{Statement of Ethics}

The PATRO Children study protocol was approved by the ethics review committee of all participating centers in accordance with national laws and regulations (online suppl. material; see www.karger.com/doi/10.1159/000515875). Patients and/or their guardians (for patients aged $<18$ years) provided written informed consent to participate in the study.

\section{Conflict of Interest Statement}

P.B., S.L., and K.O.S. are members of the PATRO Children Global Steering Committee. S.K. has acted as a speaker for Sandoz and is a member of the PATRO Children Global Steering Committee. C.H. has received lecture fees from Sandoz and is a member of the PATRO Adult Global Steering Committee. T.B.'s institution has received grants from Sandoz. R.W.P. has received lecture fees from Sandoz, Merck, Pfizer, Novo Nordisk, and Ferring and serves as an advisory board member for the PATRO Children Study in Germany. H.Z. and T.G. are employees of Sandoz. E.L. and B.K. have no relevant disclosures to declare.

\section{Funding Sources}

The PATRO Children study is funded by Sandoz Biopharmaceuticals, c/o HEXAL AG.

\section{Author Contributions}

All authors contributed to data interpretation, writing, and critical review of the manuscript and approved the final version of the manuscript for publication.

\section{References}

1 Gravholt $\mathrm{CH}$, Andersen NH, Conway GS, Dekkers OM, Geffner ME, Klein KO, et al. Clinical practice guidelines for the care of girls and women with Turner syndrome: proceedings from the 2016 Cincinnati International Turner Syndrome Meeting. Eur J Endocrinol. 2017;177(3):G1-70.

2 Folsom LJ, Fuqua JS. Reproductive issues in women with Turner syndrome. Endocrinol Metab Clin North Am. 2015;44(4):723-37.

3 Gravholt $\mathrm{CH}$, Viuff $\mathrm{MH}$, Brun S, Stochholm $\mathrm{K}$, Andersen NH. Turner syndrome: mechanisms and management. Nat Rev Endocrinol. 2019;15(10):601-14.
4 Shankar RK, Backeljauw PF. Current best practice in the management of Turner syndrome. Ther Adv Endocrinol Metab. 2018;9(1):33-40.

5 Rao E, Weiss B, Fukami M, Rump A, Niesler B, Mertz A, et al. Pseudoautosomal deletions encompassing a novel homeobox gene cause growth failure in idiopathic short stature and Turner syndrome. Nat Genet. 1997;16(1):54-63.

6 Ranke MB, Wit JM. Growth hormone: past, present and future. Nat Rev Endocrinol. 2018; 14(5):285-300.

7 Baxter L, Bryant J, Cave CB, Milne R. Recombinant growth hormone for children and adolescents with Turner syndrome. Cochrane Database Syst Rev. 2007;(1):Cd003887.
8 Deal C, Kirsch S, Chanoine JP, Lawrence S, Cummings E, Rosolowsky ET, et al. Growth hormone treatment of Canadian children: results from the GeNeSIS phase IV prospective observational study. CMAJ Open. 2018;6(3): E372-83.

9 Lee PA, Ross JL, Pedersen BT, Kotnik P, Germak JA, Christesen HT. Noonan syndrome and Turner syndrome patients respond similarly to 4 years' growth-hormone therapy: longitudinal analysis of growth-hormone-naive patients enrolled in the NordiNet(R) International Outcome Study and the ANSWER Program. Int J Pediatr Endocrinol. 2015;2015(1):17. 
10 Quigley CA, Child CJ, Zimmermann AG, Rosenfeld RG, Robison LL, Blum WF. Mortality in children receiving growth hormone treatment of growth disorders: data from the Genetics and Neuroendocrinology of Short Stature International Study. J Clin Endocrinol Metab. 2017;102(9):3195-205.

11 Ranke MB, Lindberg A, Chatelain P, Wilton $\mathrm{P}$, Cutfield W, Albertsson-Wikland K, et al. Prediction of long-term response to recombinant human growth hormone in Turner syndrome: development and validation of mathematical models. KIGS International Board. Kabi International Growth Study. J Clin Endocrinol Metab. 2000;85(11):4212-8.

12 van Pareren YK, de Muinck Keizer-Schrama SM, Stijnen T, Sas TC, Jansen M, Otten BJ, et al. Final height in girls with Turner syndrome after long-term growth hormone treatment in three dosages and low dose estrogens. J Clin Endocrinol Metab. 2003;88(3):1119-25.

13 Davenport ML, Crowe BJ, Travers SH, Rubin K, Ross JL, Fechner PY, et al. Growth hormone treatment of early growth failure in toddlers with Turner syndrome: a randomized, controlled, multicenter trial. J Clin Endocrinol Metab. 2007;92(9):3406-16.

14 Darendeliler F, Karagiannis G, Wilton P. Headache, idiopathic intracranial hypertension and slipped capital femoral epiphysis during growth hormone treatment: a safety update from the KIGS database. Horm Res. 2007;68(Suppl 5):41-7.

15 Bell J, Parker KL, Swinford RD, Hoffman AR, Maneatis T, Lippe B. Long-term safety of recombinant human growth hormone in children. J Clin Endocrinol Metab. 2010;95(1): $167-77$.

16 European Medicines Agency (EMA). Omnitrope european public assessment report (EPAR). 2018 [cited 2020 Dec 8]. Available from: https://www.ema.europa.eu/en/medicines/human/EPAR/omnitrope.

17 European Medicines Agency (EMA). Omnitrope summary of product characteristics (SmPC). 2018 [cited 2020 Dec 8]. Available from: https://www.ema.europa.eu/en/documents/product-information/omnitropeepar-product-information_en.pdf.

18 Pfaffle R, Schwab KO, Marginean O, Walczak M, Szalecki M, Schuck E, et al. Design of, and first data from, PATRO Children, a multicen- tre, noninterventional study of the long-term efficacy and safety of Omnitrope ${ }^{\oplus}$ in children requiring growth hormone treatment. Ther Adv Endocrinol Metab. 2013;4(1):3-11.

19 Hermanussen M, Assmann C, Wöhling H, Zabransky M. Harmonizing national growth references for multi-centre surveys, drug monitoring and international postmarketing surveillance. Acta Paediatr. 2012;101: 78-84.

20 Tanner JM, Goldstein H, Whitehouse RH. Standards for children's height at ages 2-9 years allowing for heights of parents. Arch Dis Child. 1970;45:755-62.

21 Hermanussen $M$, Cole J. The calculation of target height reconsidered. Horm Res. 2003; 59:180-3.

22 Iglewicz B, Banerjee S. A simple univariate outlier identifier procedure. Proceedings of the Annual Meeting of the American Statistical Association; 2001 Aug 5-9 [cited 2020 Sep 4]. Available from: https://pdfs.semanticscholar.org/7428/59704d8a79181917b01884 c813a69a16e8e3.pdf.

23 Ricotti S, Petrucci L, Carenzio G, Klersy C, Calcaterra V, Larizza D, et al. Prevalence and incidence of scoliosis in Turner syndrome: a study in 49 girls followed-up for 4 years. Eur J Phys Rehabil Med. 2011;47(3):447-53.

24 Kanumakala S, Pfäffle R, Höybye C, Kriström B, Battelino T, Zabransky M, et al. Latest results from PATRO Children ${ }^{\varpi}$, a multi-centre, non-interventional study of the long-term safety and efficacy of Omnitrope ${ }^{\circ}$ in children requiring growth hormone treatment. Presented at the European Society for Paediatric Endocrinology (ESPE) meeting, Athens, Greece [abstract]. Horm Res Paediatr. 2019; 82(Suppl 1). Abstract 89 RFC15.6.

25 Mortensen $\mathrm{KH}$, Cleemann L, Hjerrild BE Nexo E, Locht H, Jeppesen EM, et al. Increased prevalence of autoimmunity in Turner syndrome: influence of age. Clin Exp Immunol. 2009;156:205-10.

26 Mohamed SOO, Elkhidir IHE, Abuzied AIH, Noureddin AAMH, Ibrahim GAA, Mahmoud AAA. Prevalence of autoimmune thyroid diseases among the Turner syndrome patients: meta-analysis of cross sectional studies. BMC Res Notes. 2018;11:842.

27 Apperley L, Das U, Ramakrishnan R, Dharmaraj P, Blair J, Didi M, et al. Mode of clinical presentation and delayed diagnosis of Turner syndrome: a single centre UK study. Int J Pediatr Endocrinol. 2018;2018:4

28 Savendahl L, Davenport ML. Delayed diagnoses of Turner's syndrome: proposed guidelines for change. J Pediatr. 2000;137(4):455-9.

29 US Food and Drug Administration. Omnitrope highlights of prescribing information. 2017 [cited 2020 Dec 8]. Available from: https: //www.accessdata.fda.gov/drugsatfda docs/label/2010/021426s007s008lbl.pdf.

30 Lee PA, Ross JL, Pedersen BT, Kotnik P, Germak JA, Christesen HT. Noonan syndrome and Turner syndrome patients respond similarly to 4 years' growth-hormone therapy: longitudinal analysis of growth-hormone-naïve patients enrolled in the NordiNet International Outcome Study and the ANSWER Program. Int J Pediatr Endocrinol. 2015;2015(1): 17.

31 Lebl J, Průhová S, Zapletalová J, Pechová M. IGF-I resistance and Turner's syndrome. J Pediatr Endocrinol Metab. 2001;14(1):37-41.

32 Sas TC, Gault EJ, Bardsley MZ, Menke LA, Freriks K, Perry RJ, et al. Safety and efficacy of oxandrolone in growth hormone-treated girls with Turner syndrome: evidence from recent studies and recommendations for use. Horm Res Paediatr. 2014;81:289-97.

33 Zeger MP, Shah K, Kowal K, Cutler GB Jr, Kushner H, Ross JL. Prospective study confirms oxandrolone-associated improvement in height in growth hormone-treated adolescent girls with Turner syndrome. Horm Res Paediatr. 2011;75:38-46.

34 Gault EJ, Perry RJ, Cole TJ, Casey S, Paterson WF, Hindmarsh PC, et al. Effect of oxandrolone and timing of pubertal induction on final height in Turner's syndrome: randomised, double-blind, placebo-controlled trial. BMJ. 2011;342:d1980.

35 Menke LA, Sas TC, de Muinck Keizer-Schrama SM, Zandwijken GR, de Ridder MA, Odink RJ, et al. Efficacy and safety of oxandrolone in growth hormone-treated girls with Turner syndrome. J Clin Endocrinol Metab. 2010;95:1151-60.

36 Park HK, Lee HS, Ko JH, Hwang IT, Hwang JS. Response to three years of growth hormone therapy in girls with Turner syndrome. Ann Pediatr Endocrinol Metab. 2013;18:138. 